\title{
Climate variability and water resource scarcity in drylands of Rajasthan, India
}

\author{
Ram Babu Singh ${ }^{1}$ and Ajay Kumar ${ }^{2 *}$
}

\begin{abstract}
Background: The world is experiencing a high climatic variability and has its impact on all ecosystems, regions and sectors, but the nature and extent of vulnerability to climate change differs with adaptive capacity of individual, society and region. The regions which are scarce on resources are among the very vulnerable systems of the earth and most of such regions have existing extreme climatic conditions like deserts and snow covered areas. The vulnerability of arid regions is further accentuated by low levels of socio-economic development, and this is the case with arid regions of India, which leads to fast depletion of water resources.

Results: The study analyses the climate variability over last 35 years (1973-2008) in the Western drylands of Rajasthan and the results show that the temperature has shown a great variability with an average rise of about $0.5^{\circ} \mathrm{C}$ for the month of June. The maximum rise is visible during 1995-2000. The scarcity of water resource accompanied by variability creates water stress conditions in the region and is responsible for droughts. During last 35 years (1973-2008) the average annual rainfall has shown a decrease of $50 \mathrm{~mm}$. With an overall rise in temperature over the region and changing precipitation trends the humidity provinces as defined by Thornthwaite have shifted eastward.

Conclusions: The climate variability has direct impact on the water resources of the region. The low to medium rainfall in most parts, high evapo-transpiration demands for water, high frequency of occurrence of droughts resulting from the departure of rainfall from mean values, and the high per capita arable land increases the demand for irrigation water. The free power in agriculture continued for many years, and the existing pump horse power based pricing of electricity encourage over-pumping and inefficient and often wasteful use of groundwater. The advent of Indira Gandhi Canal in the fragile desert ecosystems helps the region to cope with high variability in rainfall. The study suggests that water security in the region can be attained through expansion of canal network.
\end{abstract}

Keywords: Climate variability; Arid regions; Water scarcity; Livelihood security

\section{Background}

The world is experiencing a high variability in climatic parameters. The variability is both spatial and temporal in nature. A 10 to 15 per cent increase in monsoon precipitation in many regions of India, a simultaneous precipitation decline of 5-25 per cent in drought-prone central India and a sharp decline in winter rainfall in northern India are projected (Ramesh and Yadava, 2005). Possible changes in extreme weather events may cause increase in frequency of heat waves and drought in the northern Indian region (Sen Roy and Singh, 2002). The impact on water balance, hydrology and

\footnotetext{
* Correspondence: mail_kumarajay@yahoo.com

${ }^{2}$ Department of Geography, SSN College, University of Delhi, Delhi 110036, India

Full list of author information is available at the end of the article
}

vegetation are also predicted to be severe. Climate variability has its impact on all ecosystems, regions and sectors, but the nature and extent of vulnerability to climate change differs with adaptive capacity of individual, society and region. The regions which are scarce on resources are among the very vulnerable systems of the earth and most of such regions have existing extreme climatic conditions like deserts and snow covered areas (Watson et al., 1996; Ribot Jesse 1996). Droughts, desertification, and water shortages are permanent features of life in drylands and under such conditions the increase in evapotranspiration has severe impact on agriculture, horticulture and forestry and human activities (Sharma and Bhattacharya 2006; Smith et al., 1996; Sen 
Roy and Singh, 2002). In an area dominated by arid and semi-arid lands, water is a very limited and high percentage of degraded land is there due to Aeolian processes and because soils tend to be thin, much of the rainfall runs directly off of the surface, only to infiltrate deeper soils downslope or along river beds, changes in the frequency and magnitude of rainfall events will alter the number of recharge events (Intergovernmental Panel on Climate Change 1996). The vulnerability of arid regions is further accentuated by low levels of socio-economic development, and this is the case with arid regions of India (Singh and Gurjar, 2011). The high population density of Indian desert is intensifying the pressure on the land and water resources, which leads to increased rate of land degradation and fast depletion of water resources (Kharin, 1995). Beside population pressure, climate variability also has very important role in determining the status of resources. Climate change is expected to increase the frequency and intensity of current hazards and the probability of extreme events, and also to spur the emergence of new hazards (Nicholls and Lowe, 2006). Extreme events within the variability of the climate system are, by far, the largest cause of natural disasters worldwide each year (Kininmonth, 2004).

Whatever might be the nature of climate change that bounds to occur in a region, the outcome would be large scale displacement of normal human activity. And, now the climate is changing due to human actions. Despite efforts to abate the human causes, human-driven climate change will continue for decades and longer (Intergovernmental Panel on Climate Change IPCC 2001). Global climate change, which has already impacted natural resource systems across the Earth, is adding to the pressures and is expected to substantially disrupt many of these systems and the goods and services that they provide (Millennium Ecosystem Assessment, 2005). Therefore, only climate change mitigation steps are not enough; there is an immediate need to strengthen the adaptive capacity of people and regions. Therefore in lieu of these issues the present study attempts to analyse the status and vulnerability of water resources in the western drylands of Rajasthan in context of climate variability over past 35 years (1973-2008).

\section{Study area}

The state of Rajasthan is the second largest state in India, with an area of 0.342 million sq $\mathrm{km}$ out of which 0.198 million sq $\mathrm{km}$ which is nearly 58 per cent, is occupied by Thar Desert (Figure 1). The Thar Desert is characterized by low and erratic rainfall, high evapotranspiration, large temperature variation, scanty vegetation, rodent infestation, absence of perennial rivers, sparse and nomadic population and dependence of man on animal rearing. The study area is located in the north-western part of
India between $24^{\circ} 31^{\prime}$ to $30^{\circ} 12^{\prime}$ north latitudes and $69^{\circ} 15^{\prime}$ to $76^{\circ} 42^{\prime}$ east longitudes. It is surrounded by Punjab in north, Gujarat in south, Pakistan in west and Aravalis in east. Its length is $640 \mathrm{~km}$ from north to south and width is $300 \mathrm{~km}$ from east to west. The western arid region includes 12 districts i.e. Sriganganagar, Hanumangarh, Churu, Sikar, Jhunjhunu, Nagaur, Bikaner, Jodhpur, Barmer, Jalore, Pali and Jaisalmer. The study area can be divided into two main physical regions viz. i) Sandy Arid Region and ii) Semi-Arid. The western sandy plain includes the Marusthali and the adjoining Bangar to the west of the Aravalis. It is a wide expanse of poorly watered, sterile and wind-blown sand. The general aspect of this region is of an interminable sea of sand and sand dunes of different shapes and sizes varying from 6-60 meter in height and being sometimes $3-5 \mathrm{~km}$ in length (Figure 2). Semi-Arid region is drained by Luni in its south-eastern portion. Gullying has given rise to conglomerate landscape. The land is slightly undulating within venue of sand deposited by inland drainage and stream with salt lakes (Sharma and Sharma, 2002) (Figure 3). The Western arid region of Rajasthan has a population of 22.5 million as per census data of 2001. The Indian Thar Desert is most populous desert in the world, with density of around 84 persons per sq $\mathrm{km}$. The population growth (42 per cent) is also very high between 1901 and 2001, and more than 70 per cent people lives in villages or scattered settlement called dhanis (Hamlets) where agriculture and animal husbandry are the main occupation.

\section{Research data and methodology}

The secondary data sources include historical climate data of 35 years from 1973 to 2008 of WMO standard in respect of rainfall, maximum temperature, minimum temperature and rainy days from India Meteorological Department (IMD). The temporal and spatial analysis of data has been done by using Moving average (Seven years). This tool is used to find out the trend of temperature and rainfall variation over the years. Thornthwaite and Mather Moisture index (1955) is useful in division of climate of a year into various types. The comparison of moisture indices of each month of this year with previous years is helpful in determining changes in climate for particular months in a year. Maps are used to determine the spatio-temporal change in temperature and precipitation. Arc GIS 10.0, Erdas 9.2 and Arc View 3.2 software were used for this purpose.

\section{Thornthwaite's moisture index and climate classification}

In 1948, Thornthwaite proposed a new classification of climate. The classification is based on the concept of potential evapotranspiration, which represents the amount of moisture that would be transferred to the atmosphere by evaporation of liquid or solid water plus transpiration 


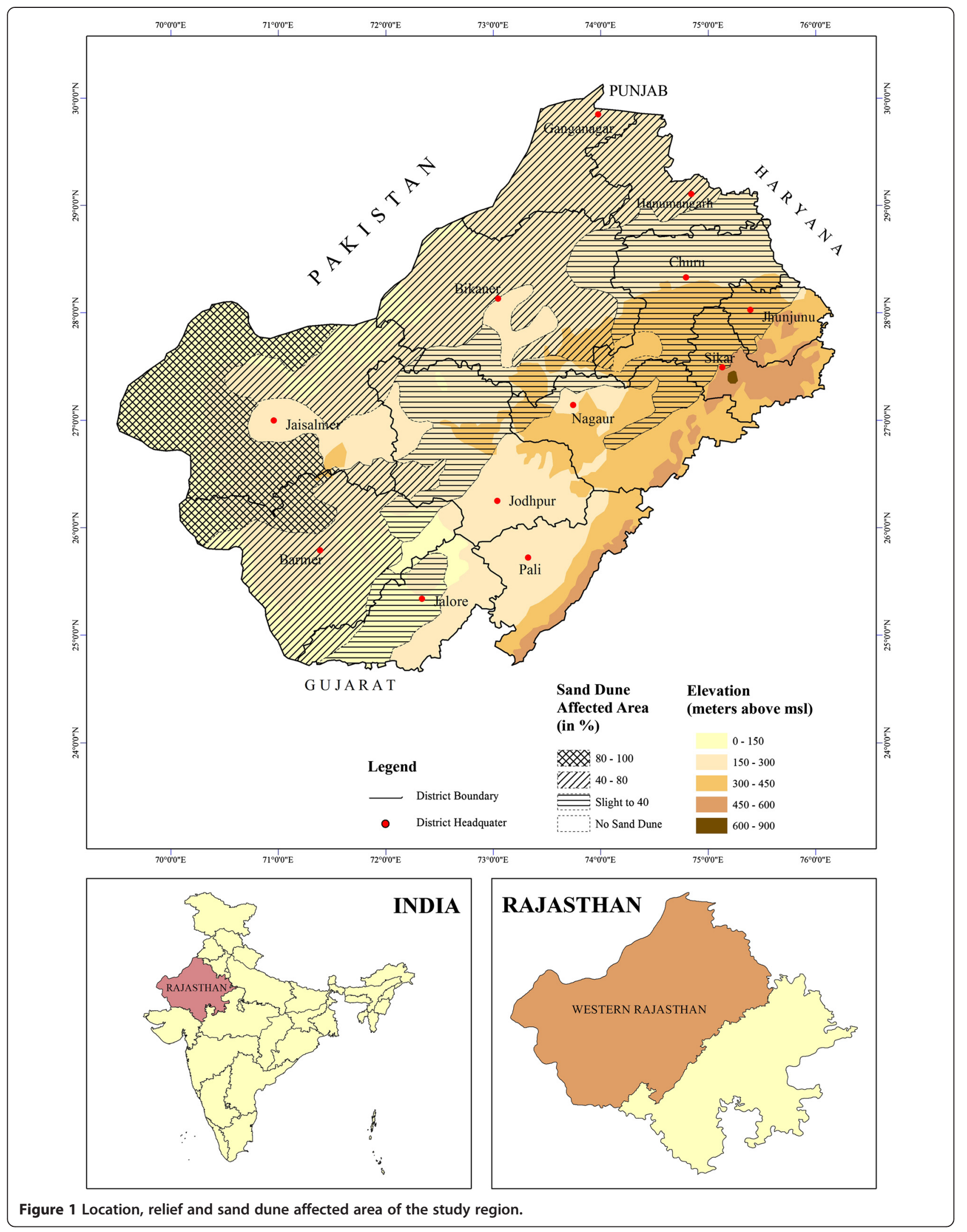




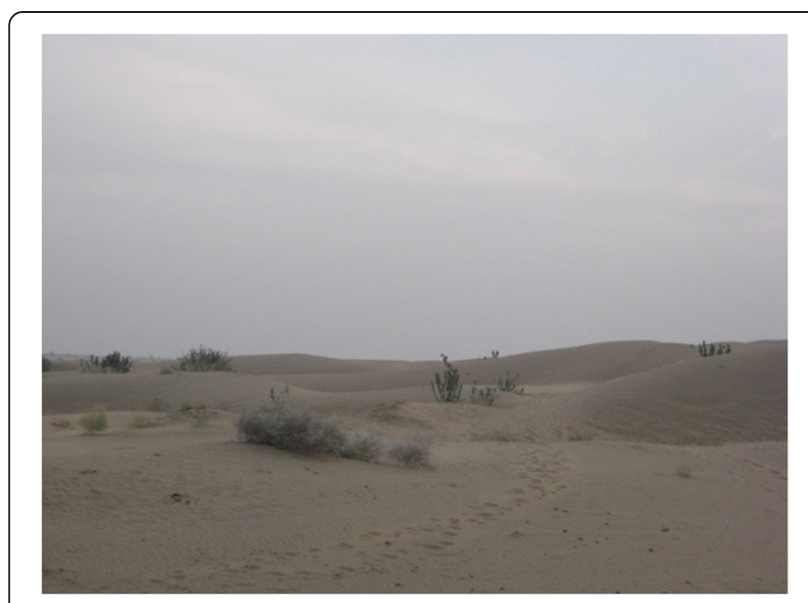

Figure 2 Sand dunes in western sandy region.

from living tissues, principally plants if it (the moisture) were available. The potential evapotranspiration $(\mathrm{PE})$ is calculated from the mean monthly temperature $\left(\right.$ in ${ }^{\circ} \mathrm{C}$ ), with corrections for day length. For a 30-day month (12-hour days):

$$
\mathrm{PE}(\text { in } \mathrm{cm})=1.6(10 \mathrm{t} / \mathrm{I})^{\mathrm{a}}
$$

where $\mathrm{I}=$ the sum of 12 months of $(\mathrm{t} / 5)^{1.514}$

$$
\mathrm{a}=\left(6.75 \mathrm{e}^{-7} \times \mathrm{I}^{3}\right)-\left(7.71 \mathrm{e}^{-512}+1.79 \mathrm{e}^{-2 \mathrm{I}}+0.49239\right) .
$$

The monthly water surplus (S) or deficit (D) is calculated from a moisture budget assessment including stored soil moisture. Thornthwaite (1948) defined the humidity province based on moisture index. A moisture index (Im) is given by the following formula:

$$
\mathrm{IM}=(100 \mathrm{~S}-60 \mathrm{D}) \mathrm{PE}
$$

Land use map is based on AWiFS sensor data taken from National Remote Sensing Agency. Secondary data

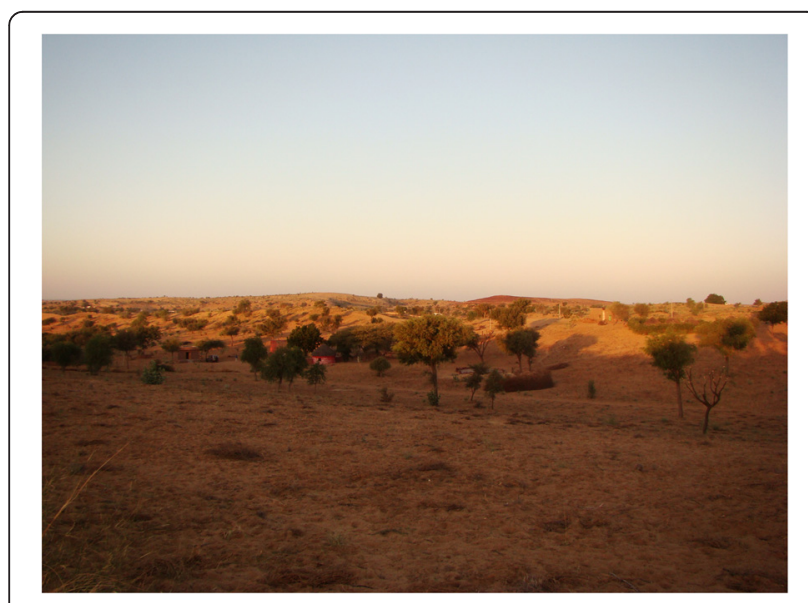

Figure 3 Undulating topography of eastern semi-arid region. pertaining to land use and cropping pattern has been collected from Directorate of Agriculture, Rajasthan and using the Weaver's method, crop diversification and combination regions have been identified. The two time data related to crop area and production has been compared and results have been analysed. Data related to water resources have been taken from Water Resource Department, Government of Rajasthan and have been analysed using different statistical methods.

\section{Results and discussion \\ Climate change} Temperature variability

In the Western Rajasthan during last 30 years the temperature has shown a great variability with an average rise of about $0.5^{\circ} \mathrm{C}$ for the month of June. The temperature rose from average temperature of $33.25^{\circ} \mathrm{C}$ in 1973 to $33.75^{\circ} \mathrm{C}$ in 2008 . The maximum rise is visible during 1995-2000. Whereas for the month of January the average rise in temperature is about $1^{\circ} \mathrm{C}$ during last 30 years. The average monthly temperature for January has increased from $15^{\circ} \mathrm{C}$ in 1973 to $16^{\circ} \mathrm{C}$ in 2008 (Figure 4). The temperature rise for January is more consistent and the fluctuations are not so abrupt as compared to June. The local factor influencing the temperature rise is increased cloud cover during winter months.

\section{Rainfall variability}

The Western Rajasthan suffers from scarcity of rainfall. The average annual rainfall in the region is measured to be $350 \mathrm{~mm}$ per year and above that the rainfall pattern in the region shows large variability and has never been consistent (Figure 5). The scarcity accompanied by variability creates water stress conditions in the region and is responsible for droughts. During last 30 years the average annual rainfall has shown a decrease of $50 \mathrm{~mm}$, it was measured $400 \mathrm{~mm}$ during 1973, which came down to $350 \mathrm{~mm}$ per annum. The decrease in precipitation can be attributed to rising temperature. As the temperature increases the moisture holding capacity of atmosphere increases and thus the condensation is delayed till further addition of moisture to the atmosphere which might lead to decrease in precipitation.

\section{Change in humidity provinces}

With an overall rise in temperature over the region and changing precipitation trends the humidity provinces as defined by Thornthwaite have shifted eastward. The results from correlation and regression matrix show that the changes in PE, which further led to change in humidity provinces, are caused by change in maximum temperature. The influence of change in minimum temperature and precipitation on PE is less as compared to impact of change in maximum temperature. In 1973 the 


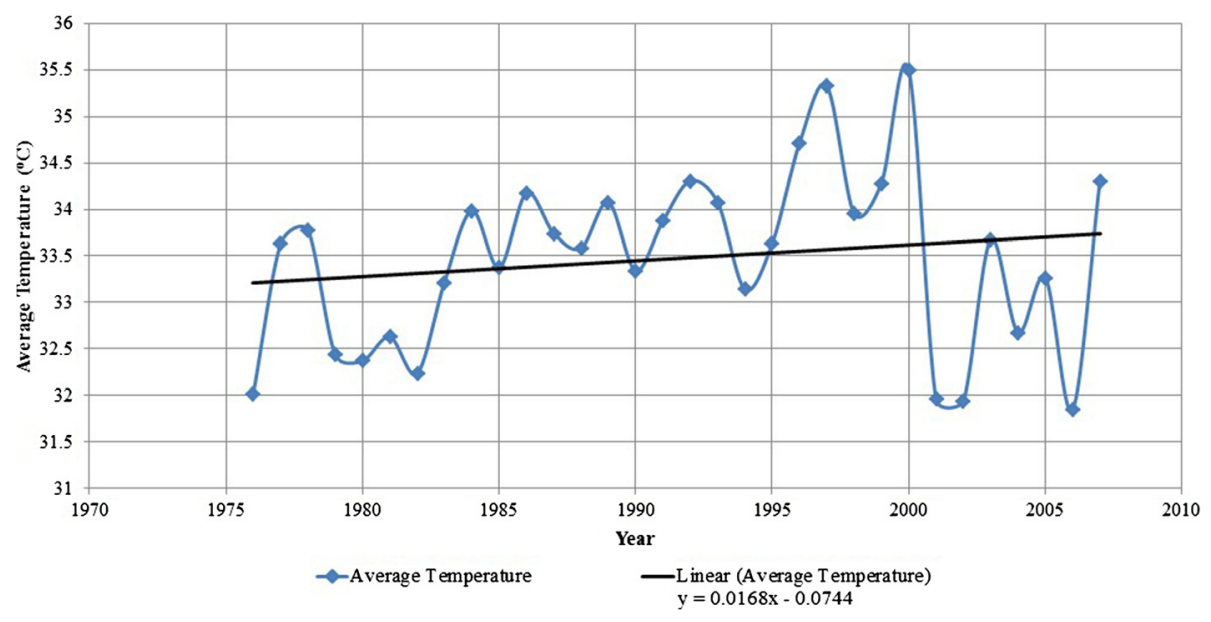

Figure 4 Temperature variation over past 35 years in Western Rajasthan during the month of January.

arid region consisted of Barmer, Bikaner, Ganganagar along with western parts of Churu, Hanumangarh, Jalore and Jodhpur, But according to 2008 meteorological datasets eastern parts of Churu, Hanumangarh and Jodhpur, and western parts of Jhunjhunu, Nagaur, Pali and Sikar have been added to arid type of humidity province. The semi-arid type of province did not include eastern margins of Pali and Sikar, but now the earlier recorded dry sub humid type of conditions in these two parts of region are replaced by semi-arid conditions (Figure 6). The region has experienced changes in moisture index, but the changes are not homogenous all over the region. Increase in aridity i.e. fall in index values have been noticed over major part of the region. Whereas a small part including of western Bikaner, northern Jaisalmer, central Barmer and western Jalore have experienced decrease in arid conditions. The increase in aridity ranges from a minimum of zero point to maximum of 28 points.

\section{Water resources}

The region is characterized by heterogeneity in groundwater conditions. The region has all formations, viz., unconsolidated, semi consolidated and fully consolidated, with varying groundwater potential. Geographically, unconsolidated extensive porous formations, with low groundwater potential cover the northern, eastern and south western parts of the region, comprising the entire Ganganagar, most parts of Churu, Pali and Barmer districts. But, there are some pockets within these unconsolidated formations which have high yields (Figures 7 and 8). These patches are in Jhunjhunu and Sikar districts. But, the groundwater underlying the entire Ganganagar and

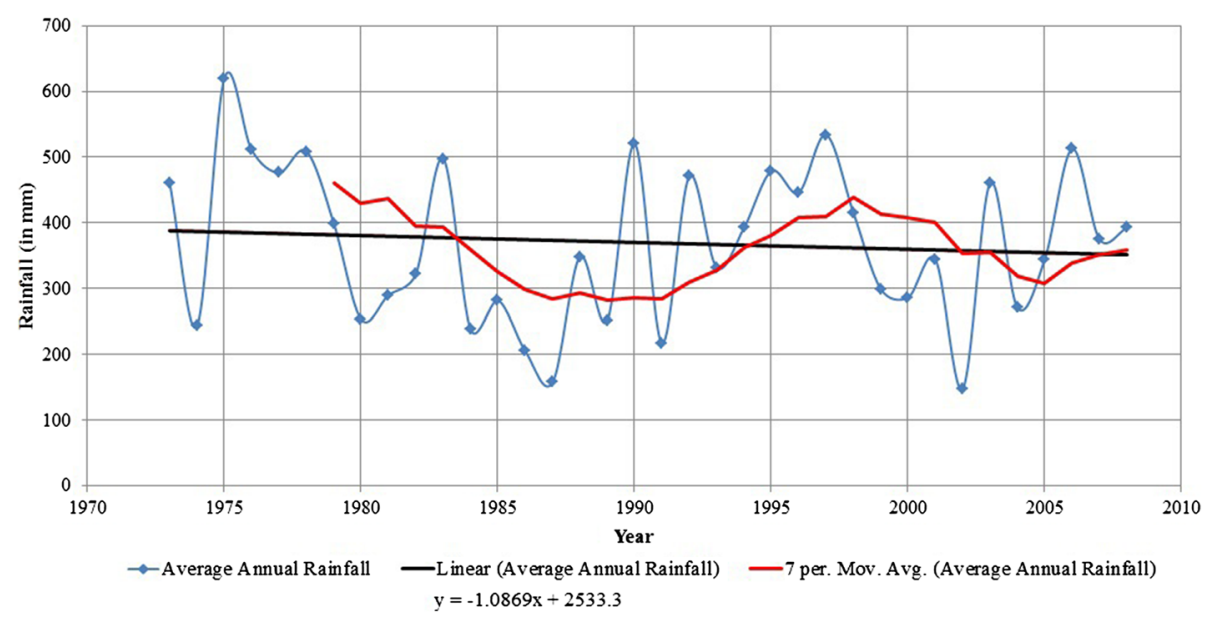

Figure 5 Variability in rainfall over past 35 years in Western Rajasthan. 


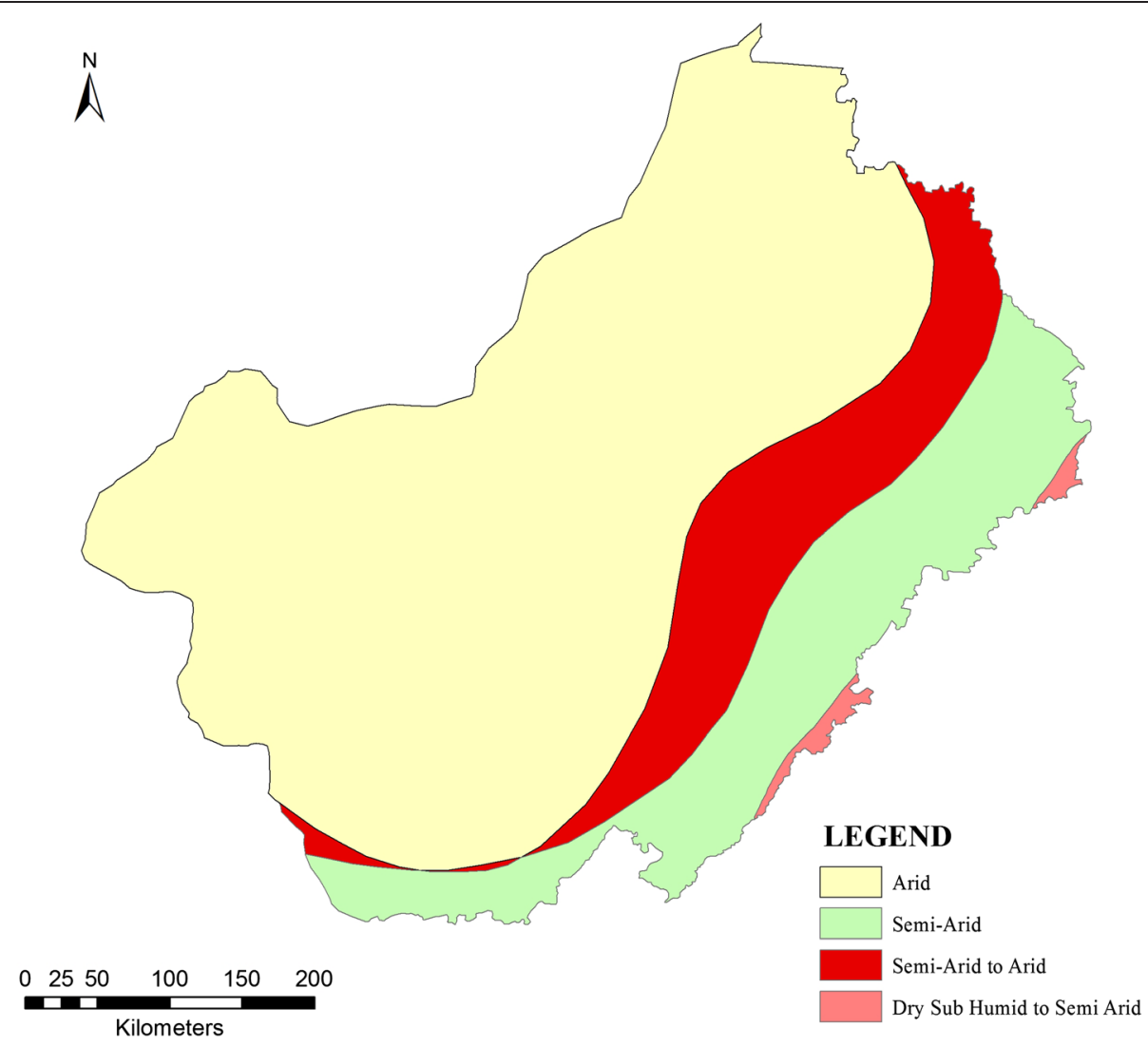

Figure 6 Shift of Thornthwaite's climate belts during 1970 - 2008.

Churu districts is saline, and therefore unfit for irrigation and drinking. Unconsolidated discontinuous aquifers with poor yield potential cover the western parts covering the Thar Desert in Jaisalmer. Most of it is saline, except some patches in the extreme west. Semi consolidated aquifers of low yield potential are found in parts of Jaisalmer, Bikaner and Churu districts. There are patches of semi consolidated aquifers with moderate yield potential in Barmer district, and high yield potential in the lower north western parts, covering parts of Bikaner and Churu

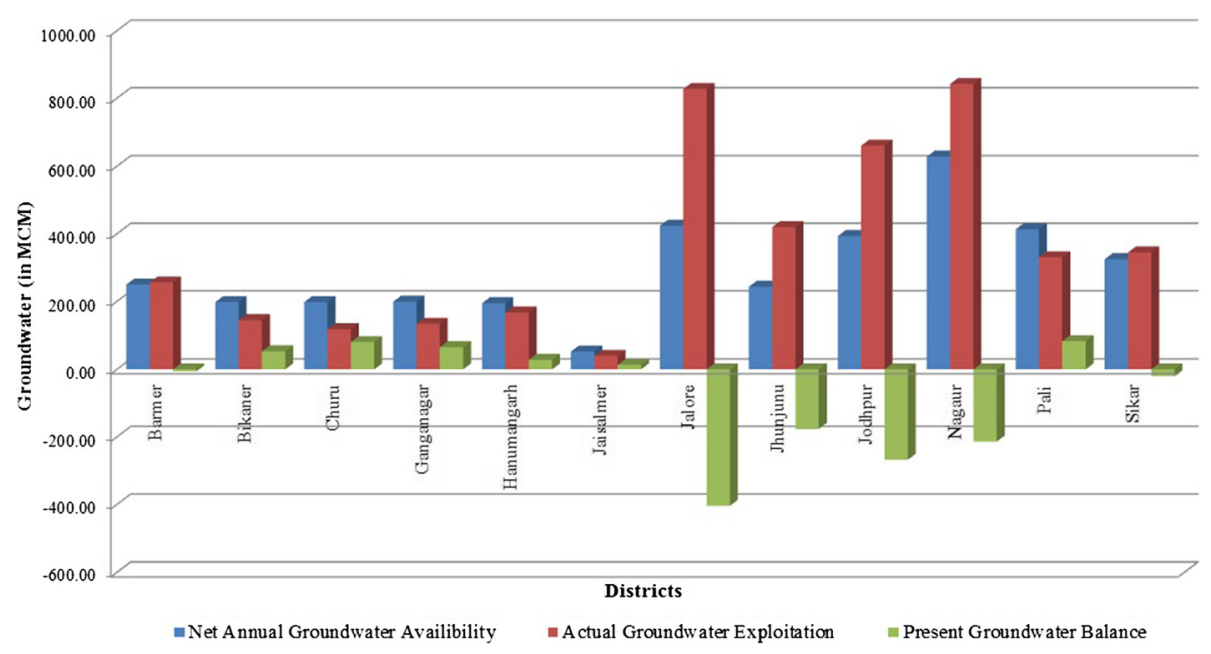

Figure 7 Groundwater resources potential of Western Rajasthan. 


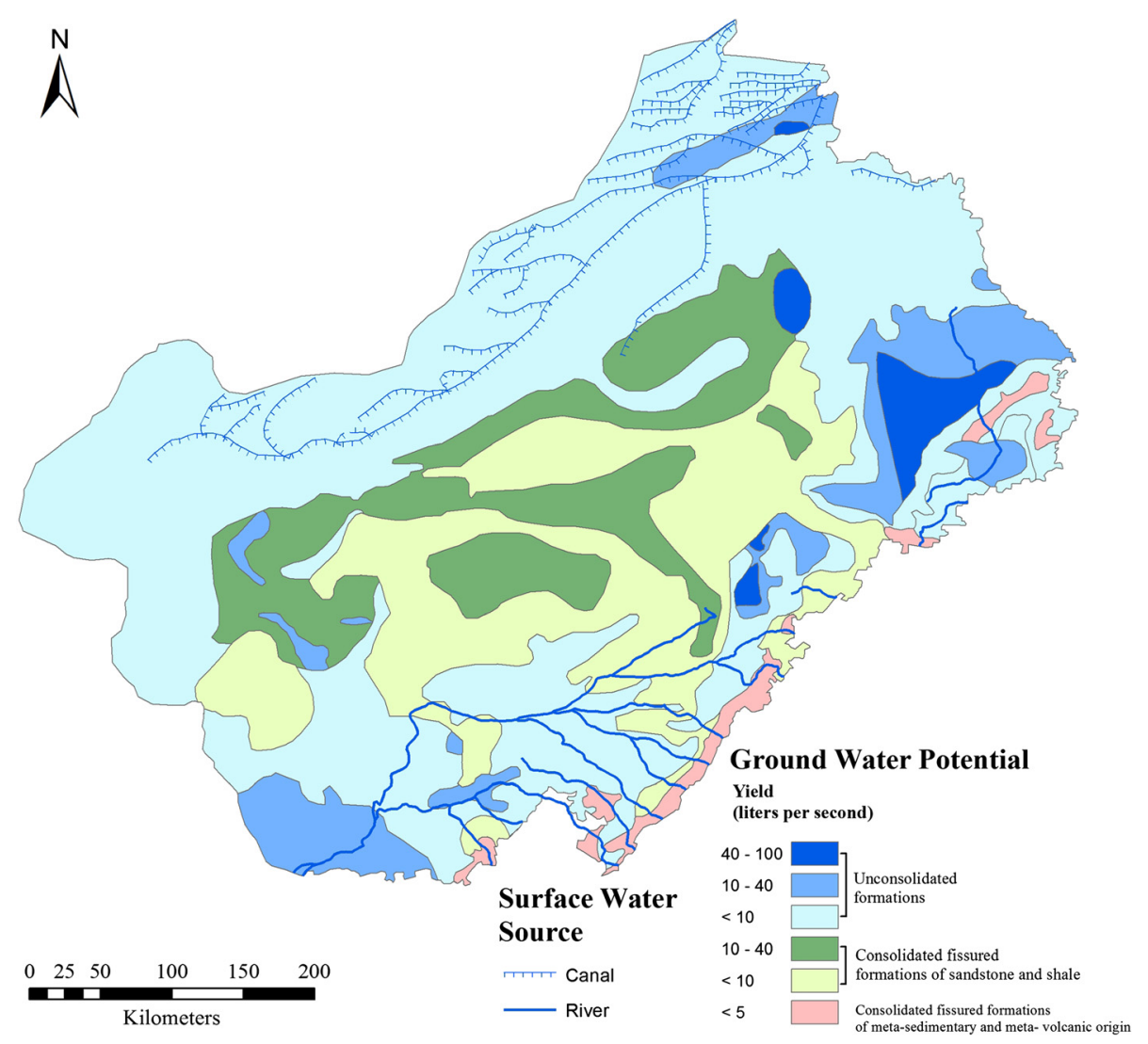

Figure 8 Surface water resources and groundwater potential in Western Rajasthan.

districts. These aquifers are inherently saline. But, over the years, the quality of groundwater in this region has improved (Kumar et al., 2009).

Consolidated fissured formations of sandstone and shale with low yield are found in Nagaur and Jodhpur districts, and that with moderate yield potential are found in other parts of Nagaur, Jodhpur and Jaisalmer districts. Consolidated limestone and dolomite formations in small patches are found in Nagaur, Jodhpur and Jaisalmer districts. Consolidated fissured formations of meta-sedimentary and meta- volcanic origin with low yield potential (1-5 lps) are found in the southern parts extending up to the central eastern part of region. They cover parts of Jalore district. Consolidated fissured sedimentary formations with low yield potential are found in parts of Jalore (Ozha and Sharma, 2011).

Rajasthan stands first in terms of degree and extent of over-exploitation of groundwater resources in the country. One reason for this phenomenon is the absence of sufficient number of large-scale surface irrigation facilities, well-spread geographically. The low to medium rainfall in most parts, high evapo-transpiration demands for water, high frequency of occurrence of droughts resulting from the departure of rainfall from mean values, and the high per capita arable land increases the demand for irrigation water. This is being met through mining of groundwater resources. The free power in agriculture continued for many years, and the existing pump horse power based pricing of electricity encourage over-pumping and inefficient and often wasteful use of groundwater.

The irrigated area by all sources was only 9.3 per cent in 1951 has increased by about 43 per cent in 2000-01 out of the total potentiality (53 per cent) of irrigation in the western Rajasthan. This expansion of irrigation has resulted inclusion of new lands, which were earlier under fallow lands, pastures and grazing and land not available for cultivation and further it caused shrinkage of pastures and grazing lands. The data reveals that depletion in groundwater level is very significant in the region. Out of total 12 districts, 10 districts in the region shows depleting trend of groundwater level. On the basis of average depletion these districts have been further classified as most critical $(>10 \mathrm{~m}$ ), critical (average depletion is between 5 to $10 \mathrm{~m}$ ) and moderate (average depletion is between 0 to $5 \mathrm{~m}$ ) (Figure 9, Tables 1 and 2). 


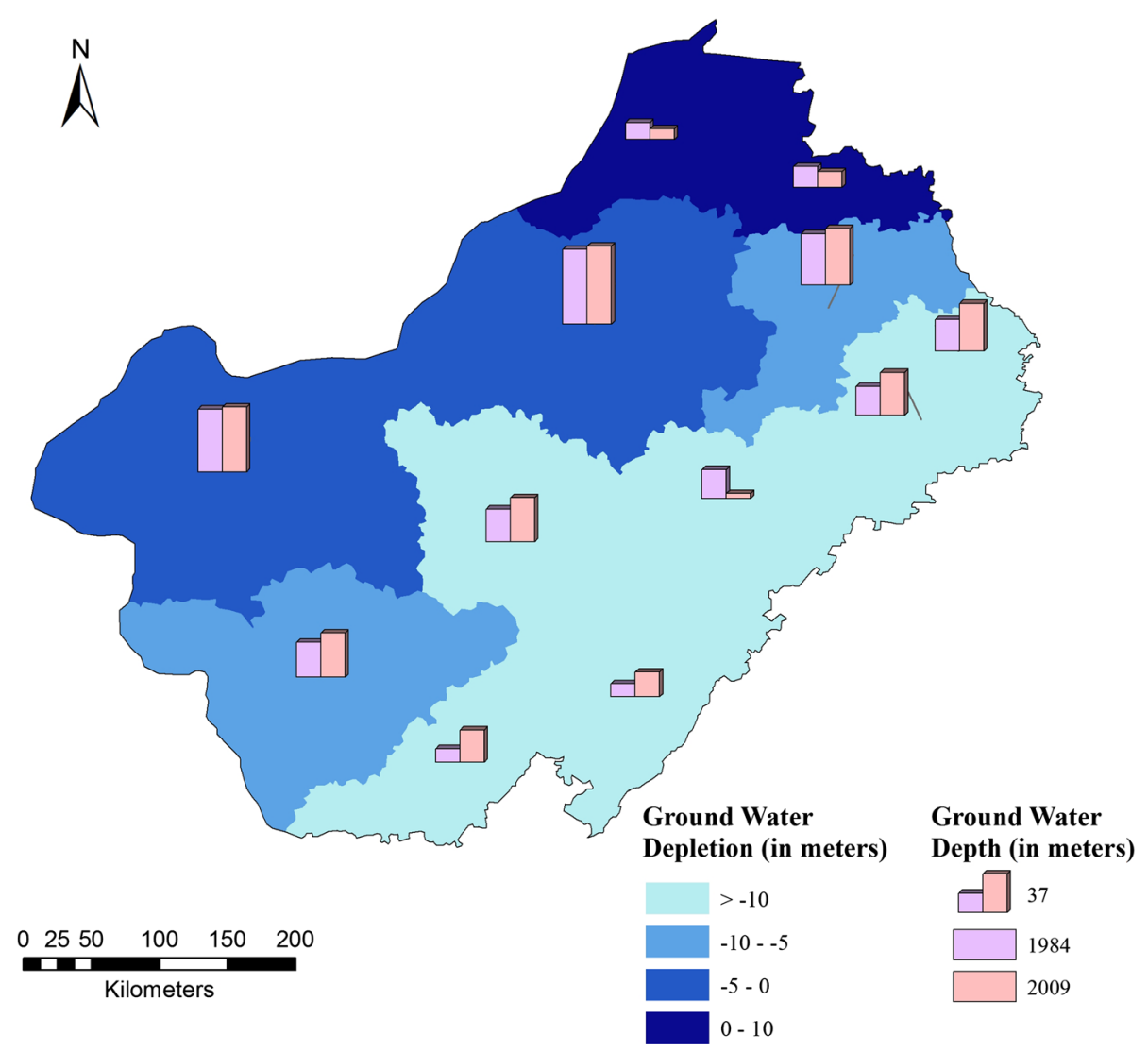

Figure 9 Groundwater depth and depletion in Western Rajasthan.

Overall, the estimated groundwater resources in Western Rajasthan are limited due to deep aquifers and low recharge. Based on the ratio of annual pumping to annual recharge, the stages of groundwater development have been categorized as safe ( $<70$ per cent), semicritical (70-90 per cent), critical (90-100 per cent) or overexploited (per cent $100 \%$ ) (Rathore, 2005; Narain et al., 2005). The groundwater is overexploited in Barmer, Jalore, Jhunjhunu, Jodhpur, Nagaur, and Sikar districts.

The advent of Indira Gandhi Canal in the northern parts of arid region of Rajasthan has led to immense change in the land use pattern of the region. The once barren land has been now converted into highly productive green belt (Figure 10). Such initiatives in the fragile desert ecosystems help the region to cope with high variability in rainfall. The scenario of land use had markedly changed during the years due to the canal irrigation. Satellite-based mapping has revealed that in arid western Rajasthan irrigated and double-cropped area has significantly increased and at the same time, the area under fallow land has declined. More area under groundwater irrigation with high inputs is coming under cash crops like groundnut, cotton, mustard, cumin and chillies. All these factors have added to the process of land degradation and has also increased the water demand in the region. It is important to note that area

Table 1 Account of withdrawal and recharge of groundwater in western Rajathan

\begin{tabular}{lllllll}
\hline Year & $\mathbf{1 9 8 4}$ & $\mathbf{1 9 9 0}$ & $\mathbf{1 9 9 5}$ & $\mathbf{1 9 9 8}$ & $\mathbf{2 0 0 1}$ & $\mathbf{2 0 0 4}$ \\
\hline A. Gross groundwater recharge & 16.22 & 12.71 & 13.16 & 12.6 & 11.16 & 11.56 \\
1. Irrigation & 4.93 & 5.42 & 9.09 & 11.04 & 10.45 & 11.6 \\
2. Domestic and Industrial & 2.11 & 1.99 & 0.7 & 0.98 & 1.18 & 1.39 \\
B. Gross Draft (1+2) & 7.04 & 7.42 & 9.78 & 12.02 & 11.64 & 12.99 \\
Groundwater balance (A-B) & 9.19 & 5.29 & 3.38 & 0.58 & -0.48 & -1.43 \\
Stage of groundwater development (\%) & 36 & 54 & 59 & 69 & 104 \\
\hline
\end{tabular}

Source: Groundwater Board, Rajasthan, 2009. 
Table 2 Status of groundwater in the western Rajathan

\begin{tabular}{llllll}
\hline Year & Block (area unit) & Safe (white) & Semi-critical (semi-gray) & Critical (gray) & Over-exploited (dark) \\
\hline 1984 & 236 & $203(86)$ & $10(4.2)$ & $11(4.7)$ & $12(5.1)$ \\
1988 & 236 & $122(54)$ & $42(18.6)$ & $18(8)$ & $44(19.4)$ \\
1990 & 236 & $148(62.7)$ & $31(13.1)$ & $13(5.5)$ & $44(19.4)$ \\
1992 & 236 & $149(63.1)$ & $19(8.1)$ & $15(6.4)$ & $53(22.5)$ \\
1995 & 236 & $127(53.8)$ & $35(14.8)$ & $14(5.9)$ & $60(25.4)$ \\
1998 & 236 & $135(57.9)$ & $34(14.6)$ & $23(9.9)$ & $41(17.6)$ \\
2001 & 236 & $49(20.8)$ & $21(8.9)$ & $80(33.9)$ & $86(36.4)$ \\
2004 & 237 & $32(14)$ & $14(6)$ & $50(21)$ & $140(59)$ \\
2009 & 236 & $30(13)$ & $8(3)$ & $34(14)$ & $164(69)$ \\
\hline
\end{tabular}

Source: Groundwater Board, Rajasthan, 2009.

under cultivable wasteland, pastures and trees, fallow land and land not available for cultivation have declined by 24.07 per cent, 13.15 per cent and 8.55 per cent respectively in the western region. This trend of gradual decrease shows that the area that was earlier under open grazing for indigenous cows and other draught animals is shrinking rapidly, placing the traditional livelihood options under threat. With advent of canal irrigation the farmers prefer commercial and food crops rather than fodder crops. During 1960's there was dominance of pastures, grazing lands and areas of fodder crops. There is a decreasing trend of food grain crops in the region. Crop diversification has increased in present for both the cropping seasons as compared to 1960. One of the main driving forces behind crop diversification is availability of water through various sources viz. canal and tube wells. The area under fodder crops was 56 per cent in 1951, has reduced to 47 per cent in $1992-93$ and about 36 per cent in 2003-04. The area under oil seeds cultivation increased from 6.2 per cent in 1951 to 21.4 per cent in 2003-04.

Besides all the physical factors, poor socio-economic conditions also accentuate the vulnerability. The region has

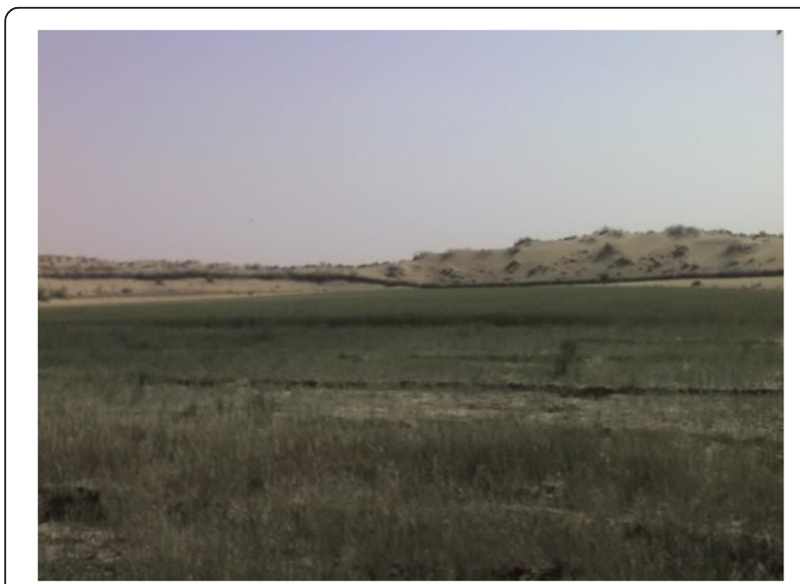

Figure 10 Agriculture amidst sand dunes due to canal irrigation. highest population density (84 persons per sq $\mathrm{km}$ ) among all arid regions of the world. The state of Rajasthan ranks low on development and literacy among the other states of India. The variability in population distribution also hampers the uniform planning, as according to the 2001 Census, Jaisalmer district, located on the western border, had a population of about half a million, accounting for about 2 per cent of total population of the region and more than 15 per cent of its area. On the other hand, Jhunjhunu district accounted for around 9 per cent of the state's population, but less than 1 per cent of its area. Therefore in order to attain sustainability and water security socio-economic conditions also need to be taken into consideration.

\section{Conclusion}

The climate over Western Rajasthan is showing definite signs of change, with decrease in rainfall and increase in temperature and aridity. The arid climate belt has shifted eastward, intensifying the process of land degradation and causing desertification. The water resources are scarce, adding to vulnerability of region towards climate change. But in last few decades there has been tremendous development of various water sources by government in the region and due to these efforts the north-western part of region has attained good agriculture production and yield. The development of canal irrigation in some parts has intensified the process of land degradation in form of salinization and alkalization, which need to be managed at priority basis in order to maximize the profit from canal. The land use pattern in the region has also changed with development of water resources. Farmers are now opting for crop diversification and commercial crops like mustard. The decrease in rainfed crops like gram can be attributed to high variability of rainfall. The central part of the region is more dependent on rainfall for agriculture which makes it highly susceptible towards impact of climate change. There is a need to develop more extensive network of canals and water harvesting structures together with diversifying the source of livelihood. 


\section{Competing interests}

The authors declare that they have no competing interests.

\section{Authors' contributions}

RB S has been instrumental in conception and design of the study. He significantly contributed to interpretation of data. He has been involved in drafting the manuscript for important intellectual content. AK has acquired the data and has substantially contributed to analysis and interpretation of data. He has done the initial drafting of the manuscript. He prepared all the maps and graphs required for the study. Both author read and approved the final manuscript.

\section{Author details}

'Department of Geography, Delhi School of Economics, University of Delhi, Delhi 110007, India. ${ }^{2}$ Department of Geography, SSN College, University of Delhi, Delhi 110036, India.

Received: 13 October 2014 Accepted: 24 February 2015

Published online: 13 March 2015

\section{References}

Intergovernmental Panel on Climate Change (1996) Climate Change 1995: IPCC Second Assessment Report. Intergovernmental Panel on Climate Change. Cambridge University Press, Cambridge

Intergovernmental Panel on Climate Change (IPCC) (2001) Climate Change 2001: Impacts, Adaptation Vulnerability. Contribution of Working Group II to the Third Assessment Report. Intergovernmental Panel on Climate Change, Geneva

Kharin NG (1995) Change in Biodiversity in Ecosystems of Central Asia under the Impacts of Desertification. United Nations, Washington DC

Kininmonth W (2004) Climate Change: A Natural Hazard. Multi Science Publishing Co. Ltd., Essesx

Kumar MD, Srinivasu VK, Bassi N, Trivedi K, Sharma MK (2009) Groundwater Management in Rajasthan: Identifying Local Management Actions. Institute for Resource Analysis and Policy, Hyderabad

Millennium Ecosystem Assessment (2005) Ecosystems and Human Well-being: Synthesis. Island Press, Washington DC

Narain P, Khan MA, Singh G (2005) Potential for Water Conservation and Harvesting against Drought in Rajasthan, India. Working Paper 104 (Drought Series: Paper 7). International Water Management Institute (IWMI), Colombo

Nicholls RJ, Lowe JA (2006). Climate stabilization and impacts of sea-level rise. In H J Schellnhuber, W Cramer, N Nakicenovic, T Wigley and G Yohe (eds). Avoiding Dangerous Climate Change Cambridge University Press, Cambridge 195-202.

Ozha DD, Sharma SK (2011). Mitigation of Water Quantity and Water Quality Challenges in Groundwater of Rajathan. Water Research and Development. 1(1):29.

Ramesh R, Yadava MG (2005) Climate and water resources of India. Curr Sci 89(5):818-824

Rathore MS (2005) Groundwater Exploration and Augementation Efforts in Rajasthan- A Review. Institute of Development Studies, Jaipur

Ribot Jesse C (1996) Climate Variability, Climate Change and Social Vulnerability in the Semi Arid Tropics. Cambridge University Press, Cambridge

Sen Roy S, Singh RB (2002) Climate Variability, Extreme Events and Agriculture Productivity in Mountain Regions. Oxford and IBH Publication, New Delhi

Sharma S, Bhattacharya S, Garg A (2006) Greenhouse gas emissions from India: a perspective. Curr Sci 90(3):326-333

Sharma HS, Sharma M (2002) Facets of Rajasthan. Kuldeep Publishers, Ajmer

Singh RB, Gurjar AK (2011) Climate change vulnerability of agriculture in arid region of Rajasthan, India. Annals of National Association of Geographers, India 31(1):31-38

Smith JB et al (1996) Considering Adaptation to Climate change in the Sustainable Development of Bangladesh. World Bank Report, World Bank, Washington DC

Thornthwaite CW (1948) An approach toward a rational classification of climate. Geogr Rev 38(1):55-94

Watson RT, Zinyoera MC, Moss RH (1996) Climate Change 1995: Impacts, Adaptations and Mitigation of Climate Change: Scientific-Technical Analysis. Contribution of Working Group II to the Second Assessment Report. Intergovernmental Panel on Climate Change. Cambridge University Press, Cambridge

\section{Submit your manuscript to a SpringerOpen ${ }^{\circ}$ journal and benefit from:}

- Convenient online submission

- Rigorous peer review

- Immediate publication on acceptance

- Open access: articles freely available online

- High visibility within the field

- Retaining the copyright to your article

Submit your next manuscript at $>$ springeropen.com 